Poznań

\title{
Challenges in evaluating impact of sanctions - political vs economic perspective
}

\begin{abstract}
The aim of this paper is twofold: to highlight the need of combining economic and political perspectives in analyzing sanctions outcomes, and to list and elaborate on challenges connected with uniting these two standpoints and creating cohesive and valid measurement methods. We not only credit this fusion as useful, but necessary to evaluate sanctions' efficiency and effectiveness. We display these challenges in sanctions' assessment and measurement by systematizing what we already know about the sanction effectiveness in political science and economics literature and by demonstrating strengths and weaknesses of some already published effectiveness evaluations. The paper is the part of the larger research project that we recently embarked upon with aim to analyze the onset, economic impact and effectiveness of sanctions imposed by the European Union ${ }^{1}$.
\end{abstract}

Key words: international sanctions, effectiveness of economic sanctions, politics of sanctions, effectiveness, efficiency

\section{Introduction}

$\mathbf{T}$ he imposition of sanctions is one of strategies that states use to coerce target countries into altering their behavior by means of economic or political pain (e.g. Cranmer, Heinrich, Desmarais, 2014). The sanctions are used as a punishment tool, or a sign of disapproval of the improper actions (see eg. Carter, 1987). Their expected (but maybe a long term) outcome is the change of so far condemned behavior, as a response to a costbenefit calculus (Kirshner, 1997, 42).

There can be different triggers that may cause the sanction regime to be initiated such as; human rights violations or swift deterioration; extreme forms of military violence abroad or political violence in a country; flawed elections or other aggressive (domestic or international) behavior. Expected outcomes of sanctions vary, but are mostly of political nature. By imposing sanctions senders expect from target countries' governments either a withdrawal of troops, an abandonment of the plans of territorial acquisition or a termination of other military adventures. Sanctions are also imposed with intentions to improve democracy performance (i.e. increase the level of democracy), enhance and protect human rights, to halt a nuclear proliferation or better protect against international terrorism (Hufbauer, Schott, Elliott, 1990).

Given a variety of sanction demands the literature differentiates between different types of sanctions: military (e.g. arms embargoes); economic and financial (restrictions on exports and imports; aid sanctions; freezing of funds or economic resources, prohibition on financial transactions, reducing investment) and political and diplomatic (e.g.

\footnotetext{
${ }^{1}$ Project financed by National Centre of Science, Beethoven UMO-2014/15/G/HS5/04845.
} 
recalling of ambassadors, expulsion of diplomats, halting diplomatic ties, suspension of official visits). Economic sanctions of different kinds are the mostly used ones and thus they receive the most attention in the scholarly literature (Drezner, 2003; Hufbauer, Schott, Elliott, 1990; Lacy, Niou; Pape, 1997). Economic sanctions serve as "the deliberate, government inspired withdrawal or threat of withdrawal, of customary trade or financial relations" (Hufbauer et al., 2009, p. 3).

However, when we consider the official statements, economic sanctions hardly ever serve purely economic purposes. The most popular and officially announced grounds for using these restrictive measures is to compel the sanctions' recipients to change their behavior, perceived as politically and socially unacceptable by the sanctions' senders. The general aim of economic sanctions is to drastically raise the costs' of the target countr(ies) transactions and, through this magnified burden, promote and cause a change in behavior. Imposing costs through economic pressure serves here as means for changing the behavior of a government in recipient country. The use of economic pressure helps to achieve desirable goals while avoiding the military intervention (Baldwin, 1985).

For more than two decades political scientists debate over the effectiveness of economic pressure (Barber, 1979; Drury, 1998; Hufbauer, Schott, Elliott, 1990; Kaempfer, Lowenberg, 1988; Marinov, 2005). A substantial part of research on economic sanctions focuses on sanction effectiveness and the conditions under which they are likely to achieve their intended policy objectives.

Even though popular and extensively debated, the issue how to measure effectiveness of economic sanctions, is still unsolved and open to many questions. The multitude of publications in this area shows lingering inconsistency in both understanding the concept of sanctions' effectiveness and its' assessment. In order to clarify the way we measure this problem we have to answer to the following questions: How do political scientists and economists understand and define sanctions' effectiveness and do these perspectives converge? How does the understanding of sanctions' effectiveness influence the way their impact is measured? Do these assessments regard effectiveness, general outcomes of sanctions or rather choose to focus on specific conditions of sanctions effectiveness?

The paper is structured as follows. Firstly, we delineate the differences between efficiency and effectiveness and then describe different approaches to studying sanction effectiveness in political literature. Consecutive sections demonstrate the lack of consensus among scholars regarding the sanction effectiveness, stemming either from different time frame taken as the basis for analysis, different methodology adopted as well as from different economic and political variables estimated. In the final section, we make some generalizations arguing that in order to precisely evaluate the impact of sanctions we should precisely define the nature of the concept we investigate together with clear-cut outline of constituencies and the types of interplays we measure.

\section{Efficiency vs. effectiveness of sanctions}

According to R. Ackoff, the efficiency of an act relates either to the amount of resources required to achieve a goal with a specified probability, or to the probability to achieve this objective with a specified amount of resources (Ackoff, 1999, p. 170). It can 
also be defined as the ratio of inputs (in economics: resources) to outputs (a specified outcome). Resources mean here both material and immaterial inputs (capital, work, land, intellectual capital, information etc.), required to obtain the outcome. The efficiency can be raised by combining physical resources with information and intellectual capital or by boosting the probability of achieving the amount of output with the same resources given to disposal. The main assumptions in evaluating the efficiency are that the outcome/goal is well specified and the costs of the process can be traced and measured. The efficiency describes the way we reach the expected outcome through rational (ie. volitional, based on identified incentives, constraints etc. ${ }^{2}$ ) costs' optimization perspective. We can estimate the level of efficiency relative to similar past events or to the other objects striving at the same direction with the same outcome in mind.

The common understanding of the term "effectiveness", however, is to conteptualise as the ability to produce the desired outcomes, regardless the costs involved. Although both terms, efficiency and effectiveness, are widely used in economics and management to describe different aspects of economic processes and their results, there is also a broader meaning, describing the organizational economic optimization (see eg. Quinn, Rohrbaugh, 1983, Steers, 1975). In the latter sense, the effectiveness is a ratio of benefits connected with the goal achievement juxtaposed to costs necessary to achieve them, but the value of these benefits is subject to an individual (object) evaluation. The important difference between effectiveness and efficiency lies in a meaning of "value"; the term that changes the way we evaluate the costs of the actions leading to the outcome. Efficiency term disregards the importance and the subjective value of the outcome. While having the same efficiency in achieving the specific goal, various actors (humans, companies, countries etc.) can differently perceive and evaluate the effectiveness of this process.

Given this differentiation between the terms as stated above, sanctions can be evaluated, as:

- efficient but ineffective (have the optimum input/output ratio, but do not produce the desired outcome),

- efficient and effective (have the optimum input/ output ratio and produce the desired outcome),

- inefficient but effective (input/output ratio is suboptimal or negative, but resulted in the desired outcome),

- inefficient and ineffective (input/output ratio is suboptimal or negative and they do not produce the desired outcome).

However, the question is whether the political scientists make such distinction between these conceptually different approaches to evaluation of sanctions. Thus, in the next sections, we present how scholars understand the effectiveness of sanctions, whether they adopt a narrow or a broad definition and whether their understanding of measuring sanction effectiveness changes with different time framework and different cost-benefit calculations.

2 Rationality in an economic understanding deals with means and ends ratio, but does not evaluate the goal itself (if it is rational or not). Rationality strives at maximizing the way and means (inputs) to reach the outcome, whatever the outcome is. Arrow (1986, p. 390) “... the everyday usage of the term 'rationality' does not correspond to the economist's definition as transitivity and completeness, that is, maximization of something. The common understanding is instead the complete exploitation of information, sound reasoning, and so forth." 


\section{Evolution in scientific focus on sanctions' analysis}

Thieler (2009) divides the sanctions literature into three phases. He points out that the first stage of studying this phenomenon was typically characterized by optimism due to the more or less effective use of this foreign policy tool to achieve its main aim. The very first works on this topic considered economic sanctions or sanction threats to be effective once they achieved a foreign policy success; the sender's objective was achieved and sanctions played an important role in this outcome. In the second phase sanction literature pulled into questioning the use of sanctions as an efficient and effective foreign policy tool. Scholars at this stage began incorporating theoretical and analytical models into their discussions to explain and predict the necessary conditions under which sanctions do and should succeed and/or fail. The third phase in sanctions analysis is saturated by skepticism and pushes towards identifying new methods achieve national agendas through a fine-tuning of sanctions (Thieler, 2009, pp. 152-153).

Despite plethora of studies regarding the effectiveness of economic sanctions in the last two decades, the mixed results of the various studies in the field show that political scientists seem to show lack of consensus regarding the usefulness of this foreign policy tool (Wallensteen, 1968, 2000; Doxey, 1971; Knorr, 1975; Barber, 1979; Olson, 1979; Kaempfer, Lowenberg, 1988, 1992; Pape, 1997). This mixed results could lie in the way the scholars define "success" of sanctions and how they measure this concept. Scientists, in their attempt to answer the questions whether and under what conditions the sanctions work focus on different areas of investigations. In many cases they do not define what they mean by sanctions effectiveness and generally investigate sanctions outcomes while stressing the conditions of sanctions' failure or success. To sum, the differences in the results obtained, stem from differences in: defining the sanctions' success, variables taken into assessment, method of assessment, as well as timeframe (sanctions' duration and their consequences in different phases of their imposition).

\section{The conditions for sanctions success}

The most popular definition of sanction success adopted by the scholars considers sanctions to be successful, and thus effective, when the target government agree to comply with pressure and sanction demands, which would not be considered or even rejected if the sanctions were not imposed. The political scientists tend to consider the sanctions as a coercive diplomacy (Art, Cronin, 2003; Lindsay, 1986; Elliott, Uimonen, 1993; Pape, 1997) and raise the question whether the pressure works - if and under what conditions the leaders are ready to compromise under the pressure applied by sanctions. The behavior of the sanction recipient country's government seems to fit with rational choice theory. Compliance with sanction demands, and thus sanction effectiveness, can be explained in terms of rational action of leaders; they would rather comply with the sender's demands than face the deterioration of their political power.

Marinov (2005) and Lektzian and Patterson (2015, p. 47) point out the effectiveness may happen if sanctions destabilize the government's position and open a bargaining 
range. Destabilization is a necessary condition for successful coercion. If sanctions reduce the wealth and political strength of governing groups (while simultaneously empowering potential challengers) then targeted governments will be more likely to make the concessions demanded by the sender country in an effort to make sanctions stop (Lektzian, Patterson, 2015). The authors also emphasize that sanctions should be considered as exogenous factors that reduce a country's exposure to international trade. If so, the Stolper-Samuelson Theorem should well explain the success of sanctions (or its failure) by showing the divergent interests of different power groups and their conflicting interests (when the owners of abundant factors will gain from free trade, and the owners of scarce resources gain from trade protection).

However, in real life the economic pressure typically takes place alongside other important developments, therefore it's challenging to disentangle these interconnected impacts (Elliott 1998). Additionally, the perception of the goal achievement and the costs/ benefits calculation can be different to each state/interest group afflicted by sanctions' imposition. As Marinov (2005, p. 565) points out "what is success and how is it measured is often contested even by the very participants in an episode."

In evaluating sanctions' outcomes we should also take into account spill - overs/externalities; other possible consequences of sanctions that do not directly relate to meeting the foreign policy goal of the sender's country or spelled-out sanction demands.

Critics of sanctions say that sanctions are never effective because they harm the civilian population more than the targeted regimes (Cotright, 2001; Seekins, 2005). Targeted, restrictive and "smart sanctions" designed to exert pressure directly on the ruling elites and avoid negative impacts on the population as a whole are difficult to design. Moreover, instead of creating dissatisfaction with the leadership, economic sanctions may make citizens in the target country blame sender countries for their economic difficulties (Galtung, 1967) and have an opposite effect. Therefore, sanctions should be tailored to hurt the government and core support groups within the target country and to benefit, or at least avoid harming, the opposition (Kirshner, 1997, p. 42; 2002). On the other side, the lack of sanctions has even been cited as contributing to the failure of some opposition groups. Some scholars point out that sanctions support the government's opposition groups, and empower opposition campaigns and thus create a pressure on the government to comply with the sanction demands. Chenoweth and Stephan (2011) refer to sanctions against the apartheid in South Africa, that were critical in creating a bargaining space for the resistance campaigns to come to the negotiating table. These examples suggest that sanctions strengthen the opposition's voice and its credibility, raising its importance on the domestic political arena.

The studies presented above show that scholars attach different meanings to understanding the sanction effectiveness. Some of them adopt institutional explanations, claiming that the effectiveness depends who is the target state, as well as rational choice theories to explain under what conditions the elites may change the behavior in line with sanction demands. Other scholars go beyond narrowly understood effectiveness and examine the broader impact of sanctions. The differences between studies on sanction effectiveness stem also from different methodology, cost-benefit calculus and time framework are taken into account by the researchers as discussed in the next sections. 


\section{Methodological approaches in evaluating the impact of economic sanctions and their implications}

The early studies about sanctions (before 1990) took a static view on the changing conditions during and post sanctioning episodes using case study approaches for their analysis. These case-study approaches can effectively be described as documentary, rather than basing discussions upon theoretical frameworks and the identification of variables affecting outcomes (eg. Hanlon, Omon, 1987). These authors neglect theoretical frameworks for their discussion, but also were unable to take a long term perspective on outcome (Thieler, 2009).

In 1987, Black and Cooper published the first attempt at an analytical sanctions model. The model developed primarily focused on measuring the welfare losses of states in terms of consumer and producer surpluses. According to the authors, the identification of surpluses provided a way for classifying whether or not sanctions had succeeded in their efforts. This model did not attempt to identify the necessary conditions for success; however, it began the discussion on how to identify whether or not sanctions had achieved to coerce a nation away from its course of action (Thieler, 2009, p. 153).

In 1990 the most cited sanctions literature was published by Hufbauer, Schott, and Elliot. These scholars moved beyond a simple qualitative research approach to a quantitative research study of more than 100 sanctioning episodes. (Thieler, 2009, p. 154). This study became the basis for future scholars to frame their discussions on the topic. Hufbauer et al. estimated effectiveness of sanctions imposed between 1914 and 1990 using the gravity theoretical model and regression estimation technique. In original research, they surveyed experts and constructed a "policy result", as well as a "contribution of sanctions to policy results" (all on an ordinal scale of 1-4), to measure the success or failure of economic sanctions (Shojai, Root, 2013). Also other scholars used gravity model approach, an estimation of the impact of economic negative sanctions on international trade. For example Caruso studied panel gravity estimates of bilateral trade between the U.S. and 49 target countries over the period 1960-2000, inclusive (e.g., Caruso, 2003).

Dashti-Gibson et al. (1997) used the same data collected by Hufbauer but employed a logistic regression model to estimate effectiveness of sanction episodes from 1914 to 1989 in achieving their respective goals. They questioned the statistical construction of the dependent variable used by Hufbauer et al. and, instead, developed a binary dependent variable that assumes a value of one for success and zero for failure episodes. They consider six dependent variables to explain success or failure of sanctions. These include cost of sanctions to both target and sending country, political stability and economic health of the target, the duration of sanctions, whether sanctions are financial or trade sanctions, and a secular trend variable (see Shojai, Root, 2013).

Shin, Choi and Luo (2005) presented theoretical explanations about the impact of sanctions on target countries' economies, and collected extensive empirical data to test such theoretical connections in following areas: international trade; foreign direct investment; and foreign portfolio investment. They collected the sanctions data from the Threat and Imposition of Sanctions (TIES), World Bank's (2012) and World Development Indicators (WDI). Cross-national, time-series data analysis of 133 countries during 
the period from 1970 to 2005 showed that, regardless of the number of senders, the type of sanctions or the level of anticipated costs to the target and the sender, economic coercion damages none of the economic conditions of the target country. Their data analysis shows that economic sanctions have no relation to these three economic activities of target countries, whether the sanctions are imposed by the U.S. or a multilateral coalition, and whether the sanctions are embargo, financial, or severe cost type, etc. They also pointed out that an economic embargo does not really hurt the economic conditions of a target country and that business firms do not necessarily lose on trade with sanctioned countries (Shin, Choi, Luo, 2005, pp. 2-3).

Some studies over sanctions effectiveness are not so extensive in data - mining, but elegantly show the point that the author is making. Marinov (2005) used panel data from 136 countries from over 37 years and found out that the presence of sanctions against a government leader in a given year makes her or him significantly more likely to lose power in the following year (Marinov, 2005, pp. 564-565).

\section{The importance of time framework in evaluation of the sanctions' effectiveness}

While judging the effectiveness of restrictive measures, the time span of analysis is of a crucial importance. The economic consequences of such sudden external changes differ considerably when we measure them in the period of an institutional turmoil or eg. in a new equilibrium situation. New institutional economics perspective ${ }^{3}$ allows treating sanctions' imposition as an abrupt, external change of the formal rules of the game (see eg. North, 1993). Transactions costs are suddenly raised for all actors suffering from this change (in senders', target and third countries already involved in operations in a target country). Some of present and already anticipated future benefits are lost, new procedures, alternative plans and behaviors have to be invented, an additional time and capital needs to be invested in order to recognize the nature of change and develop new ways of functioning on the market. As some old mechanisms of playing the game have proven illegal, irrelevant or inefficient, the new ways and solutions have to be created in order to survive and prosper on the market.

Over the time a new equilibrium will be established with a different transaction costs' and benefits ratio, where the losses will be mediated by new opportunities discovered and new resources (eg. capabilities, information) acquired. However, the important question remains: how much time (and costs born) is needed to establish this new point of equilibrium? Sanctions endurance and the level of harm they cause is of crucial importance here, as the stronger they disturb and persist, the higher the probability of their effectiveness. Sanctions effectiveness over time is the function of the demand and supply elasticity of banned/restricted resources, together with their substitution possibility. Resources' flows restrictions would likely work better, if the banned resources are used extensively in the target country, conform substantially to GDP creation and are hardly replaceable (e.g. have no or few local substitutes with the target country turning towards an autarkic market).

${ }^{3}$ New institutional economics composes of a historical, political and transaction costs economics stream. 
A mid-term success of an imposed sanction can be a conflict or political turmoil in the target country (Kaempfer, Lowenberg, 1988; Marinov, 2005; Nossal, 1989), that would lead in a long term to expected local and international governmental reshuffles and finally to a profitable economic transactions for those countries, who had properly foreseen sanctions' outcomes and prepared to optimize their benefits. According to Hovi et al. (2005) sanctions can be considered effective even if they do not result in a desired policy shifts, but deteriorate the international position of a target country, by symbolically signaling the international disapproval for its actions.

Lektzian and Patterson (2015) test sanctions' effectiveness with use of Stolper-Samuelson theorem and prove empirically, that the sanctions bring better results over the long period of time, once they harm owners and intensive users of abundant factors in countries with open-trade policies or when they are imposed on scarce factors in countries closed to trade. These important findings shed a new light on sanctions' effectiveness evaluation. Firstly, they show the need to analyze sanctions effectiveness through the prism of resources elasticity and their substitution effect over time ${ }^{4}$. At the same time they open new areas for future investigation, as the broader the group of resources examined, the more imprecise the elasticity indicators. The importance of the given resources' investigations brings us to the next section - sanctions' costs calculation.

\section{The costs and benefits calculation in sanctions' outcomes evaluation}

The sanction, in order to be effective, has to deprive the recipient country of the present and future benefits in a way that would divert the actions of the ruling elites into the desired (by a sender) ones. Effective sanctions reshape the policy of the target country in a relatively short time and with a less amount of costs than benefits involved. But the sanctions do not hit the political power groups directly; they do so through the influence of other, economic or public/social actors.

Soest and Wahman (2015) make a point, that the imposition of sanctions or sanction threats happens according to cost-benefit calculus of the sender country, which includes three elements: 1) the domestic and global pressure to impose sanctions on the target; 2) target vulnerability; 3 ) the anticipated sender costs (if political and economic costs are low, sanction senders are more likely to impose sanctions). The sanction effectiveness is already calculated when sanctions are imposed; when the target is more vulnerable the likelihood of success is greater.

According to Caruso "the efficacy of sanctions as an instrument of foreign policy is still in great doubt. One of the main features in this kind of works is the focus on the costs of sanctions" (Caruso, 2003, p. 2). Thus, in order to calculate the expected effectiveness of sanctions we need to determine the correlation between the costs/benefits ratio for economic, social and political groups (either affected by a sanction or gaining from change caused by its operation) and the elasticity to change of those holding the political power.

Some studies (eg. Nooruddin, 2002; Drury, 1998; Hufbauer et al., 1990; Lam, 1990; Lindsay, 1986) show the positive correlation between the level of economic costs im-

${ }^{4}$ The substitution effect decreases over time, as novel ways to switch into alternative resources are invented. 
plied by sanction in a target country and an increased probability to achieve political goals, but there are still doubts to its existence (Major, McGann, 2005, p. 339). These contradictory results can stem from:

- the different definition and then examination of interest groups that are hit by or gain from the sanctions' imposition (see eg. Lektzian, Souva, 2007; Major, McGann, 2005; Kaempfer, Lowenberg, 1988),

- a different period of sanctions' operation,

- different political and social settings of a target countries, resulting in a different "impact factor" together with the curvilinear nature of elasticity function.

The "impact factor" means here the level of political responsiveness towards social or economic pressure. Political power groups may be more responsive and willing to change the behavior when the threat of losing the future benefits will gain on the probability in a short time (e.g.. forthcoming elections, sudden rise of political opponents' power) or the future consequences are unacceptable for present power elites (e.g.. imprisoning thread, war). Evaluating the propensity of power elites to change the local statecraft has to be done with one important stipulation; real threads and future benefits losses can be disregarded due to e.g.. inability to anticipate them or the tendency to underestimate their future impact.

Proper and precise costs' calculation of sanction not only requires finding out the objects bearing its' costs (ie. costs centers), but also demands costs' categorization, identification and finding the universal method of its quantification. As some of the costs can be easily quantified (as they are reflected in FDI downturns, export/import and capital shifts etc.), the others; such as costs of capabilities, procedural adjustment elicited by sanctions are largely not reflected in account books of the companies, but are also highly subjective. The most problematic stays measurement of social harm caused by sanctions.

But measuring sanctions' impact on target countries economy may result in a conclusion that they are efficient, but ineffective. The empirical findings support this efficiency and effectiveness disjunction (Bonetti, 1998; Jing, Kaempfer, Lowenberg, 2003; Nooruddin, 2002). However, according to Bapat "even when we consider the cost of sanctions, which many see as the most important predictor of sanctions success, the empirical findings are not conclusive" (Bapat et al, 2013, p. 80). A significant portion of the research do not guide policymakers as to when and how an economic sanction may be effective.

Economists have analysed the phenomenon of negative sanctions in several ways. For example, Bhagwati and Srinivasan (1976) and Tolley and Wilman (1977) note that the trade embargo on a country's imports can be analyzed as a market-disruption phenomenon. The findings show that the optimal response of an economy does not depend only upon government choices (e.g. tariffs or subsidy), but also on the behavior of individuals consumers and producers. In non-embargo periods domestic suppliers tend to increase production and demanders decrease consumption. Thus, the marginal value of consumption raises less than the marginal cost of production (Caruso, 2003, pp. 7-8).

Another scholars point out that the potential economic effectiveness of sanctions depends on their oligopoly power in restricting sales and raising prices (e.g Bayard et al., 1983). The larger is the share of exports controlled by a cartel of exporters, the easier it is to inflict damage. Thus, sanctions are likely to be more effective if they do not need to 
rely on many small exporters to control a large share of world exports. This cost-benefit calculus also includes the benefits and costs for a sender's country. Sender countries have reason to avoid imposing sanctions if the restriction of business transactions with target states may undermine their companies' competitiveness relative to foreign firms (Bapat, Kwon, 2014; Dorussen, 2009).

\section{Conclusions}

Measuring the success of economic sanctions is challenging. The literature has identified many determinants of sanctions success, but the empirical findings showing the impact of particular factors on sanctions' effectiveness have been inconclusive. The question - are sanctions effective? - still remains open to discussion, as the answer to it is so far given with a different understanding of a term discussed, with a usage of variety of different (and often institutionally incomparable) sanctions cases, with different time framework analyzed and divergent indicators and relations examined.

In order to measure the effectiveness of sanctions, the necessary conditions (and one of the major challenges) is to identify and then to estimate precisely:

- their expected outcomes; not only economic, but also social, political, environmental ones; but it would be elusive and unachievable to measure all these areas with a usage of one, compound method due to the different categories of costs and benefits involved;

- the time framework available for the goal achievement, together with the time span, when the sanctions consequences will appear and affect various interest groups on respective analytical levels;

- the types of resources and interest groups restricted/harmed by sanctions' imposition and, stemming from these, the amount of costs/benefits ratio, that the sanctions will bear (before, during and after their enforcement) to these groups.

Another challenge lies in the sanctions' goal composition; interconnectedness of political, social and economic purposes (both publically exposed and those behind diplomatic curtains) together with subjective value attached to them.

The economic tools used and their consequences are auxiliary and are supposed to lead to political shifts in a target country behavior. But in order to anticipate the effectiveness of these restrictive tools we have to not only know the amount of "harm" caused by sanctions on economic and social interest groups, but to learn its possible impact on political elites. Economically efficient sanctions, that have produced the desired economic outcome and have proven efficient in a given period of time, can stay politically ineffective, as they inadequately elicit groups in power to implement governmental or institutional revisions. Although it seems possible (although not unproblematic) to measure the economic impact of respective sanctions on various interest groups in a given period of time, there is still a major challenge (both for economics and political science academics) to find convincing tools to grasp and measure this impact on political elites and then to anticipate the response to this impact. The question is rather not about the strength of this impact, but - again - about its effectiveness and efficiency. 
Another challenge in sanctions effectiveness assessment lies in the ability to learn the expected outcomes behind sanctions. Official announcements do not necessarily expose all motives and grounds behind sanctions. Certain economic and/or political benefits for the sender countries, that could be achieved via these restrictive measures have to stay behind the scenes, but may serve as important trigger (maybe more important than official ones) for sanctions' imposition. Sanctions can for example:

1) divert the attention of local public and political opponents from domestic economic/ political problems and concentrate efforts towards battle against the external "enemy" - a sanction sender;

2) bulwark or foreshadow a further, military intervention in the region (the one that proliferates in e.g. valuable resources or serves as a promising market for the senders' country goods and services);

3) strengthen the political position of the senders' country on international arena, that will consequently transmit into economic gains (e.g. through the mandate to set new rules of the international economic and political game).

Discovering the palette of grounds behind the sanctions changes the way we evaluate their effectiveness. If the goal of a sanction is to maintain power in a senders' country (by diverting attention from local problems), its effectiveness should be judged in terms of a time span and costs closely related to the outcome achievement in a senders' country. Economic and social consequences (for the senders', target country or on an international arena) together with possible policy changes will be side-effects of the sanction imposition, regardless their present scope and future impact.

Evaluation of sanctions' effectiveness differs at meta, macro, micro and individual scale level, as the different outcomes are anticipated and respectively different types of costs and benefits should be calculated. As sanctions often serve as a last non-military diplomatic tool to change/stop unacceptable behavior of the target country, the costs of implementing such restrictive measures should not only be calculated in collation with benefits they would yield, but relatively to the costs of alternative military actions and their outcomes. For enterprises operating in the given institutional framework, sanctions imposition raises the transactions costs in the short run, but can serve as an incentive to look for new business opportunities. Stable and predictive business environment lessens transaction costs and helps to build relational trust between the partners but can also act as a structural inertia amplifier. Sudden external changes of environmental constraints (here legal bans imposed by sanctions) raise the costs of present and future business cooperation, but the level of trust between the partners serves as the solid basis for future business restoration.

By elaborating above, we believe, that clarifying the viewpoint (e.g. a macro, sender's country, long-term, political, goal - achievement perspective) in sanctions assessments, together with specifying (if taken into account) the types of costs and benefits analyzed, would greatly enhance the possibility to find confluences and disparities between the results. Then we would not only be able to better see the grounds for inconclusive results but also, by building on already existing research body, find more tuned methods to investigate the causes and interplays between sanctions' efficiency and effectiveness. 


\section{Bibliography}

Ackoff R. L. (1999), Ackoff's Best: From Data to Wisdom, John Wiley \& Sons, New York, pp. 170-172.

Art R. J., Cronin P. M. (2003), The United States and Coercive Diplomacy, The United States Institute for Peace, Washington.

Bapat N. A., Heineich T., Kobayashi Y., Morgan C. T. (2013), Determinants of Sanctions Effectiveness: Sensitivity Analysis Using New Data, "International Interactions", vol. 39, no. 1.

Barber J. (1979), Economic sanctions as a policy instrument, "International Affairs", vol. 55, pp. 367-384.

Carter B. E. (1987), International Economic Sanctions: Improving the Haphazard US Legal Regime, "California Law Review", vol. 75, no. 4, pp. 1162-1278.

Caruso R. (2003), The Impact of International Economic Sanctions on Trade: An Empirical Analysis, Peace Economics, "Peace Science and Public Policy", vol. 9, no. 2.

Chenoweth E., Stephan M. J. (2011). Why Civil Resistance Works: The Strategic Logic of Nonviolent Conflict, Columbia University Press.

Cooper A. Drury (1998), Revisiting Economic Sanctions Reconsidered, "Journal of Peace Research", vol. 35, no. 4/July, pp. 497-509.

Dashti-Gibson J., Davis P., Radcliff B. (1997), On the Determinants of the Success of Economic Sanctions: An Empirical Analysis, “American Journal of Political Science”, vol. 41, no. 2, pp. 608-618.

Doxey M. P. (1971), Economic sanctions and international enforcement, Macmillan, London.

Drezner D. W. (2003), The Hidden Hand of Economic Coercion, "International Organization", vol. 57, no. 3, pp. 643-659.

Elliott K. A (1998), The Sanctions Glass-Half Full or Completely Empty?, "International Security", vol. 23, no. 1, pp. 50-65.

Elliott K., Uimonen P. (1993), The Effectiveness of Economic Sanctions with Application to the Case of Iraq, "Japan and the World Economy", vol. 5, no. 4, pp. 403-409.

Galtung J. (1967), On the Effects of International Economic Sanctions with Examples from the Case of Rhodesia, "World Politics", vol. 19, no. 3, pp. 378-416.

Hanlon J., Omon R. (1987), The sanctions hand book, New York.

Kaempfer W. H., Lowenberg A. D. (1988), The Theory of International Economic Sanctions: A Public Choice Approach, “American Economic Review”, vol. 78, no. 4, pp. 786-793.

Kaempfer W. H., Lowenberg A. D., Mertens W. (2004), International economic sanctions against a dictator, "Economics and Politics", vol. 16, pp. 29-51.

Elliott K. A., Hufbauer G. C., Schott J. J. (1990), The Big Squeeze: Why the Sanctions on Iraq Will Work, Outlook Section, "Washington Post", December 9.

Knorr K. (1975), The Power of Nations: The Political Economy of International Relations, Basic Books, New York.

Lacy D., Niou E. M. S. (2004), A Theory of Economic Sanctions and Issue Linkage: The Roles of Preferences, Information, and Threats, "Journal of Politics", vol. 66, pp. 25-42.

Lam Peng Er. (2007), Japan's Quest For "Soft Power": Attraction and Limitation, "East Asia”, vol. 24, no. 4, pp. 349-363.

Lektzian D., Patterson D. (2015), Political Cleavages and Economic Sanctions: The Economic and Political Winners and Losers of Sanctions, "International Studies Quarterly", vol. 59, no. 1, pp. 46-58.

Lektzian D., Souva M. (2007), An Institutional Theory of Sanctions Onset and Success, "Journal of Conflict Resolution”, vol. 51, no. 6, pp. 848-871.

Lindsay J. M. (1986), Trade Sanctions As Policy Instruments: A Re-Examination, "International Studies Quarterly", vol. 30, no. 2, pp. 153-173. 
Major S., McGann A. J. (2005), Caught in the crossfire: Innocent bystanders as optimal targets of economic sanctions, "Journal of Conflict Resolution", no. 49, pp. 337-359.

Marinov N. (2005), Do Economic Sanctions Destabilize Country Leaders?, “American Journal of Political Science", vol. 49, no. 3.

Martin L. L. (1992), Coercive Cooperation: Explaining Multilateral Sanctions, Princeton University Press, Princeton, N.J.

Nooruddin I. (2002), Modeling Selection Bias in Studies of Sanctions Efficacy, "International Interactions", vol. 28, no. 1, pp. 59-75.

North D. (1993), The new institutional economics and development, "EconWPA Economic History", (January), pp. 3-6.

Olson R. S. (1979), Economic coercion in world politics: With a focus on north-south relations, "World Politics" vol. 31, pp. 471-494.

Pape R. (1997), Why Economic Sanctions Do Not Work, "International Security", vol. 22(2), pp. 90-136.

Peksen D., Drury A. (2010), Coercive or Corrosive: The Negative Impact of Economic Sanctions on Democracy, "International Interactions", vol. 36, no. 3.

Peksen D., Peterson T. (2016), Sanctions and Alternate Markets, "Political Research Quarterly", 69, no. 1.

Quinn R. E., Rohrbaugh J. (1983), A Spatial Model of Effectiveness Criteria: Towards a Competing Values Approach to Organizational Analysis, "Management Science", vol. 29, no. 3, pp. 363-377.

Schimmelfennig F., Scholtz H. (2008), Legacies and Leverage, "European Union Politics", pp. 187-215.

Shin G., Choi S.-W., Luo S. (2015), Do Economic Sanctions Impair Target Economies?, "International Political Science Review", doi: 10.1177/0192512115590203.

Shojai S., Root S. P. (2013), Effectiveness Of Economic Sanctions: Empirical Research Revisited, "International Business \& Economics Research Journal", vol. 12, no. 11.

Steers R. M. (1975), Problems in the Measurement of Organizational Effectiveness, "Administrative Science", vol. 10(4), pp. 546-558.

Thieler R. (2009), Economic Trade Sanctions: A Literature Review (1980-2005), "Executive Journal", vol. 29, p. 4.

Van Bergeijk P. (1989), Success and Failure of Economic Sanctions, "Kyklos", vol. 42, no. 3.

Wallensteen P. (1968), Characteristics of economic sanctions, "Journal of Peace Research", vol. 5, pp. 248-267.

Wallensteen P. (2000), A century of economic sanctions: A field revisited, Uppsala Peace Research Paper no. 1, Department of Peace and Conflict Research, Uppsala University, Sweden.

\section{Wyzwania w ocenie wpływu sankcji - perspektywa polityczna a ekonomiczna}

\section{Streszczenie}

Cel tego artykułu jest dwojaki. Pierwszy, to podkreślenie konieczności połączenia perspektywy ekonomicznej i politycznej w ocenie skutków sankcji. Drugi, to diagnoza i analiza wyzwań związanych z połączeniem tych perspektyw w taki sposób, aby stworzyć spójny oraz rzetelny merytorycznie i metodycznie sposób pomiaru tego zjawiska. Połączenie perspektywy ekonomicznej i politologicznej uznajemy nie tyle za pożyteczne, co niezbędne do prawidłowej oceny efektywności i skuteczności sankcji. Wyzwania związane $\mathrm{z}$ integrowaniem perspektyw i wypracowaniem narzędzi pomiaru prezentujemy przez pryzmat krytycznej analizy dotychczasowych badań dotyczących oceny skuteczności 
i efektywności sankcji, ukazując każdorazowo mocne i słabe strony zastosowanego podejścia. Artykuł jest częścią większego projektu dotyczącego przesłanek, ekonomicznego wpływu i skuteczności sankcji nakładanych przez Unię Europejską.

Slowa kluczowe: sankcje międzynarodowe, skuteczność sankcji gospodarczych, polityka sankcji, skuteczność, efektywność 